\title{
Effects of Reduced Rates of Two Insecticides on Enzyme Activity and Mortality of an Aphid and Its Lacewing Predator
}

\author{
L. H. BOOTH, ${ }^{1,2,3}$ S. D. WRATTEN ${ }^{1}$ AND P. KEHRLI ${ }^{1,4}$
}

\begin{abstract}
By applying insecticides at lower rates of active ingredients per unit area, survival rates of the pests' natural enemies can be enhanced, whereas pest mortality can remain high. The effects of reduced application rates of the insecticides lambda-cyhalothrin and dimethoate on the mortality of bird cherry-oat aphid, Rhopalosiphon padi (L.), and lacewing Micromus tasmaniae Walker were determined in the laboratory and field. Cholinesterase (ChE) and glutathione S-transferase (GST) activities in survivors provided a measure of sublethal effects and general fitness. In the laboratory, lacewings were less sensitive than aphids to both insecticides, and dimethoate was more toxic than lambda-cyhalothrin. However, these results could not be recreated in the field, in part due to very low recapture rates. In summary, lambda-cyhalothrin seemed to have no effect on aphids, but it was toxic to lacewings. Dimethoate was far less toxic in the field, but aphids were still more sensitive than were lacewings. Cholinesterase activity was reduced by dimethoate exposure in the laboratory in both species, but there were species-specific differences. Dimethoate and lambda-cyhalothrin had no effects on GST activity in either species. The high mortality rate for lacewings and aphids exposed to dimethoate in the field suggests that the application rate could be reduced to as low as $10 \%$ of that recommended by manufacturers, and this should still be highly efficacious against aphids, while protecting the predatory lacewing. Measurement of enzyme activity could provide a useful indicator of "fitness" of survivors.
\end{abstract}

KEY WORDS pesticides, biological control, enzyme biomarkers, mortality rates

Invertebrate pests destroy an estimated $37 \%$ of U.S. crops each year, which corresponds to approximately US $\$ 50$ billion in lost food and fiber production annually (Pimentel et al. 1997). Insecticides are routinely applied to manage these pests. However, there are many negative aspects of the intensive use of insecticides, including nonspecificity, development of insecticide resistance in pest species, accumulation and persistence of the compounds in the environment, and nontarget effects on beneficial insects (Burn et al. 1987, Dent 2000).

There has been much research into ameliorating the negative effects of overuse of insecticides by using an integrated pest management (IPM) approach. The concept of IPM began with the work Stern et al. (1959), with the introduction of concepts of economic thresholds, economic injury levels, and integrated control. The term IPM was first introduced in 1967 by Smith and van den Bosch (1967) and the ultimate aim of IPM is to achieve long-term pest suppression (Poehling 1989). An important step in IPM is to use pesti-

\footnotetext{
${ }^{1}$ National Centre for Advanced Bio-Protection Technologies, P.O. Box 84, Lincoln University, Canterbury, New Zealand.

${ }^{2}$ Landcare Research, P.O. Box 69, Lincoln 8152, Canterbury, New Zealand.

${ }^{3}$ Corresponding author, e-mail: boothl@landcareresearch.co.nz.

${ }^{4}$ Unit of Ecology and Evolution, Department of Biology, University of Fribourg, Ch. du Musée 10, CH-1700 Fribourg, Switzerland.
}

cides selectively to maintain populations of beneficial species. One way of achieving this may be by using reduced application rates of insecticides. Pesticide application rates specified by manufacturers typically lie well beyond the upper asymptote of the doseresponse curve, to ensure eradication of the pest. At these concentrations, the pesticides are nonselective and will probably kill both pest and prey species, but as the dose rates are reduced species-specific selectivity can occur (Poehling 1989). Information on this approach dates from the 1960s (van den Bosch and Stern 1962, Madsen and Williams 1968, Metcalf 1980). More recently, Poehling (1989) conducted a semifield test with winter wheat (Triticum spp.) and showed increasing differences in toxicity between target and nontarget species as dose rates of fenvalerate and pirimicarb were reduced. Specifically, at a dosage rate of fenvalerate that was still toxic to the aphid, mortality of syrphid larvae was reduced by $75 \%$. These results also have been validated in open field trials (Poehling 1988a,b, 1989). Reducing pesticide application rates not only reduces impacts on beneficial species, which can then contribute to pest suppression, but also reduces impacts on the environment (Poehling 1989). Furthermore, reduced dose rates can be financially viable practices with aphicides in cereals (Wiles and Jepson 1995), and Mann et al. (1991) demonstrated 
better economic returns when reduced rates were applied.

Most research into the effects of pesticides on pests or beneficial invertebrates has been conducted in controlled laboratory experiments, where mortality is usually the only parameter assessed, with no attention given to the condition and ecological fitness of the survivors (Syrett and Penman 1980, Krishnamoorthy 1985, Zuazua et al. 2003). However, sublethal insecticide exposure can lead to physiological and behavioral changes in the organism (Hyne and Maher 2003). These responses can be measured using specific biomarkers that provide a measure of sublethal effects, e.g., "fitness" of the survivors (McCarthy and Shugart 1990). Two such biomarkers are cholinesterase (ChE) activity and glutathione $S$-transferase (GST).

Cholinesterase is the target enzyme for organophosphate and carbamate pesticides, which act by inhibiting its activity. Cholinesterase activity in several terrestrial and aquatic invertebrates can be significantly decreased by sublethal exposure, and this enzyme may be a sensitive biomarker to assess environmental contamination by these pesticides (Edwards and Fisher 1991). Changes in ChE activity have long been used to diagnose organophosphorus poisoning in birds and fish, along with other measurements such as chemical residues or behavioral changes (Day and Scott 1990). Rumpf et al. (1997) demonstrated reductions in ChE activity in lacewings after exposure to azinphos-methyl and methyl parathion, and dimethoate also can inhibit ChE activity (Engenheiro et al. 2005). In general, if ChE activity is reduced by $>50 \%$, it is associated with mortality and knockdown (Edwards and Fisher 1991). Effects on ChE activity have been related to behavioral responses in invertebrates exposed to dimethoate (Jensen et al. 1997, Engenheiro et al. 2005). Significant relationships were established between locomotor activity and ChE activity in wood lice (Engenheiro et al. 2005). Changes in the former can reflect the fitness of an individual, and thus indicate the ecological relevance of measuring ChE activity. Booth and O'Halloran (2001) have shown that inhibition of ChE activity in earthworms exposed to organophosphates is linked to the ecologically relevant endpoints, growth and fecundity. Therefore, measurement of ChE activity can provide "early warning" of potential sublethal or chronic effects of insecticide exposure on both the pest and predator species.

GST is involved in the detoxification of a wide range of xenobiotic chemicals. In insects, GST plays an important role in biotransformation of various insecticides (Motoyama 1980, Lamoureux and Rusness 1987), including the degradation of some organophosphorus compounds (Yang 1976). Also, GST activity in insects and other animals is induced by many chemicals, including insecticides such as lindane, dimethoate, carbaryl, and permethrin (Lagadic et al. 1993, Parkes et al. 1993, El-Sharkawy et al. 1994), and resistance to pesticides in many insects has been attributed to higher than normal GST activity (Oppenoorth et al. 1977, Lagadic et al. 1993). GST activity in lacewings exposed to cypermethrin for $10 \mathrm{~h}$ showed a 1.5-fold increase over controls (Rumpf et al. 1997) and Spodoptera littoralis (Boisduval) exposed to lindane for $8 \mathrm{~h}$ also showed a 1.5-fold elevation in GST activity over controls (Lagadic et al. 1993). Dimethoate also has been shown to induce GST activity in rats, but this was only after repeated oral dosing (El-Sharkawy et al. 1994).

Neuroptera, and more specifically the chrysopid Chrysoperla carnea Stephens, are beneficial insects that have been extensively studied as biological control agents (Rumpf et al. 1997, Gautam and Tesfaye 2000, Solomon et al. 2002). However, C. carnea is not found in New Zealand, but the lacewing Micromus tasmaniae Walker is a native species, and it is abundant in agroecosystems (up to 200 lacewings per $\mathrm{m}^{2}$ ) and is ubiquitous in pastures and crops in New Zealand (Rumpf et al. 1997). It is a general predator of other insects and mites and is easily cultured in the laboratory, making it a good candidate for use in IPM. In this context, knowledge of the effect of a number of commonly used insecticides on this insect and on one if its prey species, the bird cherry-oat aphid, Rhopalosiphum padi (L.), is a prerequisite to its further development as a biocontrol agent in agricultural regimes in which insecticide use is a component. Two insecticides commonly used for control of aphids in cereals in New Zealand and elsewhere are the pyrethroid lambda-cyhalothrin and the organophosphate dimethoate. Dimethoate is expected to inhibit $\mathrm{ChE}$ activity and potentially to induce GST activity, and there is some literature to support this hypothesis (ElSharkawy et al. 1994). There are no reports, however, of anticholinesterase effects of lambda-cyhalothrin, but the pyrethroid cypermethrin has been shown to induce GST activity in lacewings (Rumpf et al. 1997).

The aims of this research were to assess the effects of reduced pesticide application rates of lambda-cyhalothrin and dimethoate on the mortality of the bird cherry-oat aphid and M. tasmaniae. Cholinesterase and GST activities were measured in survivors to provide a measure of sublethal effects and general fitness. The effects of the pesticides were examined in the laboratory under controlled conditions, and also in the field, by using insects caged on maize, Zea mays L., plants.

\section{Materials and Methods}

Insect Rearing. A laboratory colony of M. tasmaniae was derived from adults collected in Canterbury, New Zealand. Larvae and adults were reared in plastic boxes ( 400 by 220 by $90 \mathrm{~mm}$ ) and fed pea aphids, Acrythosiphon pisum (Harris). Adult lacewings also were supplied with a dilute honey solution. Lacewings were maintained in a controlled environment room at $20^{\circ} \mathrm{C}$ with a $4^{\circ} \mathrm{C}$ range and $50 \% \mathrm{RH}$, with a photoperiod of 16:8 (L:D) h.

All experiments were conducted with age-synchronized larvae that had molted from second instar (L2) to third instar (L3) within the previous $12 \mathrm{~h}$. Stage L3 larvae were chosen because first instars $(\mathrm{L} 1)$ and L2 
larvae experience high natural mortality $(>50 \%)$, whereas L3 larvae are generally more robust $(<10 \%$ mortality). Furthermore, L3 larvae are the most mobile instar, and consume large numbers of aphids, both of which increase their potential for exposure to pesticides in the field (Rumpf 1994).

Pea aphids and bird cherry-oat aphids were obtained from a culture at Crop and Food Research, Lincoln, Canterbury, New Zealand. Both aphid species were reared in Perspex boxes ( 0.5 by 0.5 by $0.5 \mathrm{~m}$ ) in a controlled environment room at $20^{\circ} \mathrm{C}$ with a $4^{\circ} \mathrm{C}$ range, $50 \% \mathrm{RH}$, and a photoperiod of 16:8 (L:D) h. Pea aphids were reared on young broad bean, Vicia faba L. 'Cole's Dwarf plants, and bird cherry-oat aphids were reared on young barley, Hordeum vulgare $\mathrm{L}$. 'Regatta' plants.

Pesticides. The pesticides used in this research were the pyrethroid Karate Zeon (50 g lambda-cyhalothrin/liter) and the organophosphate Perfekthion (400 g dimethoate/liter). These pesticides are commonly used on cereals and vegetable crops in the Canterbury region for control of foliar and other pests. The recommended application rates for these pesticides in cereal crops are $40 \mathrm{ml} /$ ha in 200 liters of water for Karate and $600 \mathrm{ml} / \mathrm{ha}$ in 200 liters of water for Perfekthion.

Laboratory Experiments. Laboratory exposures were conducted in 5-cm plastic petri dishes. Pesticide solutions were prepared as aqueous suspensions of up to the recommended application rate $(0.1-10 \mathrm{mg} /$ liter for lambda-cyhalothrin and $0.12-1,200 \mathrm{mg} /$ liter for dimethoate) immediately before the experiment. Lacewing L3 larvae and alate adult aphids were exposed to a minimum of six different treatment doses of each insecticide to determine the $\mathrm{LC}_{50}$ value. The pesticide solutions and a water control were subsequently applied using a micropipettor to the bottom of the petri dish and also to a piece of filter paper of the same diameter as the dish. The dishes and filter papers were allowed to dry for $1 \mathrm{~h}$.

The exposure chambers were assembled by adding $0.3 \mathrm{ml}$ of water to an unsprayed filter paper and fitting it into the lid of the petri dish to maintain humidity. The sprayed filter paper was then placed over the wet one and pushed into the lid. Five lacewing L3 larvae or five winged adult aphids were placed in the bottom of each dish and the lid fixed onto the dish, thus exposing the insects to the pesticide by direct contact with the contaminated surfaces. Pea aphids were provided ad libitum to the lacewings to prevent cannibalism. Lacewing and aphid mortality and knockdown behavior were recorded at $24 \mathrm{~h}$. For each treatment there were four replicate plates, and the experiment was conducted twice. At the end of the exposure period surviving animals were removed and frozen at $-80^{\circ} \mathrm{C}$ for subsequent enzyme analysis.

Field Experiments. For each of the two species (aphid and lacewing) and each pesticide, six application rates $(0,1.0,3.2,10,32$, and $100 \%$ of recommended application rates) were tested in a randomized threefactor block design. This resulted in 12 treatments for each species. Experiments were conducted on flow- ering maize 'Pioneer Hybrid 39K38' in a commercial field owned by Heinz Wattie's New Zealand Ltd. near Hornby, Canterbury, New Zealand. Within the field there were five 10-m wide strips of plants (blocks), and within each block the twelve treatments were randomly assigned.

Pesticides were applied using a precision hand-held sprayer. Plants were sprayed and left to dry for $1 \mathrm{~h}$. Laboratory-bred lacewing L3 larvae were placed into muslin bags (10 by $10.5 \mathrm{~cm}$ ) with laboratory-reared pea aphids provided as a food source. Winged adult aphids also were placed in muslin bags and all bags were tied to the flag leaf. Invertebrates were retained on plants for $24 \mathrm{~h}$, and then removed and mortality was assessed. Surviving animals were frozen at $-80^{\circ} \mathrm{C}$ until enzyme analysis.

Enzyme Activity Analysis. Enzyme activity and total protein concentration of the samples were determined in 96-well microtiter plates by using a Reader 340 ATTC and the Biolise software 2000 package, version 1.6 (SLT Instruments, Salzberg, Austria). Protein concentrations were determined using the method of Bradford (1976) with bovine serum albumin (Sigma-Aldrich, St. Louis, MO) as a standard and Coomassie Blue G250 reagent.

Cholinesterase Activity Analysis. Frozen samples of lacewings and aphids were defrosted on ice and maintained on ice at all times. Cholinesterase activity was measured based on the method of Ellman et al. (1961), which was modified for microtiter plates. Lacewings samples were prepared from a minimum of three excised larval heads, whereas aphid samples were prepared from a minimum of three whole bodies. Samples were homogenized in $60 \mu \mathrm{l}$ of cold temperature phosphate buffer $\left(0.02 \mathrm{M} \mathrm{KH}_{2} \mathrm{PO}_{4}, \mathrm{pH} 7.5\right)$, by using a glass homogenizer and maintained on ice for $60 \mathrm{~min}$ before analysis. The enzyme assay was conducted using acetylthiocholine iodide (ATChI) as the substrate and 5,5-dithiobis-2-6-nitrobenzoic acid (DTNB) as the color reagent at final concentrations of 1.5 and $0.5 \mathrm{mM}$, respectively. The reaction mixture containing buffer, enzyme homogenate, and DTNB was incubated at $27^{\circ} \mathrm{C}$ for 5 min and the reaction was started by the addition of ATChI. Each sample was measured in triplicate and was repeated if the coefficient of variation was $>25 \%$. Activity was determined by measuring the change in absorbance at $405 \mathrm{~nm}$ over $5 \mathrm{~min}$. The specificity of the cholinesterase assay was determined using a negative blank (no enzyme homogenate). Activity was expressed as nanomoles of acetylthiocholine hydrolyzed $/ \mathrm{min} / \mathrm{mg}$ protein.

GST Activity. Activity was measured based on the method of Habig et al. (1974) and modified for microtiter plates. Samples consisted of a single whole larva or aphid homogenized with a glass homogenizer in $100 \mu \mathrm{l}$ of cold temperature phosphate buffer $(0.02$ $\mathrm{M} \mathrm{KH}_{2} \mathrm{PO}_{4}$ ) containing $2 \mathrm{mM}$ reduced glutathione (GSH) to prevent enzyme oxidation. The homogenate was centrifuged at $15,000 \mathrm{rpm}$ for $5 \mathrm{~min}$ at $4^{\circ} \mathrm{C}$, and the supernatant was used as the enzyme source. The assay was conducted by incubating $1 \mathrm{mM}$ 1-chloro-2,4-dinitrobenzene (CDNB), the enzyme substrate, with 
Table 1. Toxicity of lambda-cyhalothrin and dimethoate to lacewings and aphids in the laboratory and in the field

\begin{tabular}{|c|c|c|c|c|}
\hline Insecticide & Species & $\mathrm{n}$ & Slope + SE & $\mathrm{LD}_{50}(95 \% \mathrm{CL})(\mathrm{mg} /$ liter $)$ \\
\hline \multicolumn{5}{|l|}{ Laboratory } \\
\hline \multirow[t]{2}{*}{ Lambda-cyhalothrin } & Lacewing & 120 & N.D. & N.D. \\
\hline & Aphid & 240 & $0.35+0.04$ & $1.057(0.9-1.23)$ \\
\hline \multirow[t]{2}{*}{ Dimethoate } & Lacewing & 310 & $14.8+1.9$ & $2.04(1.79-2.36)$ \\
\hline & Aphid & 200 & $0.14+0.03$ & $0.24(0.08-0.38)$ \\
\hline \multicolumn{5}{|l|}{ Field } \\
\hline \multirow[t]{2}{*}{ Lambda-cyhalothrin } & Lacewing & 51 & N.D. & N.D. \\
\hline & Aphid & 83 & N.D. & N.D. \\
\hline \multirow[t]{2}{*}{ Dimethoate } & Lacewing & 56 & N.D. & N.D. \\
\hline & Aphid & 75 & $0.81+0.06$ & $11.5(9.5-13.5)$ \\
\hline
\end{tabular}

ND, no dose response

$6 \mathrm{mM}$ GSH in phosphate buffer for $5 \mathrm{~min}$ at $27^{\circ} \mathrm{C}$, and the reaction was started by addition of the enzyme homogenate. The GST in the sample catalyzes the conjugation of CDNB to glutathione producing S-2,4dinitrophenyl glutathione, and enzyme activity is monitored spectrophotometrically at $340 \mathrm{~nm}$. Activity is expressed as nanomoles of GSH conjugated/ $\mathrm{min} / \mathrm{mg}$ protein. Each sample was measured in triplicate and was repeated if the coefficient of variation was $>25 \%$.

Statistical Analysis. Data from the dose-response and enzyme experiments were analyzed by analysis of variance (ANOVA) to determine whether there were differences between the experiments conducted on different days. If there were no significant difference, the data were pooled for analysis. LC values and confidence intervals were calculated at $24 \mathrm{~h}$ by probit analysis in GENSTAT. Enzyme data were analyzed using ANOVA in GENSTAT in which linear and quadratic trends were examined. Data were log-transformed before analysis. The relationship between mortality and ChE activity was analyzed using Pearson's correlation coefficient $(r)$.

\section{Results}

Laboratory Exposure Experiments. Mortality. The dose-response experiments performed on different days showed no significant differences for either lacewing or aphid tests for either pesticide; therefore, data from individual days were pooled for analysis. Pesticide-induced behavioral changes (knockdown) were dose-dependent, whereas the behavior of control insects remained unchanged throughout the $24 \mathrm{~h}$ trial, with larvae and aphids remaining active.
The $\mathrm{LC}_{50}(24 \mathrm{~h})$ for lacewings exposed to lambdacyhalothrin was not able to be determined due to insufficient mortality, even at the normal field application rate $(10 \mathrm{mg} /$ liter) (Table 1$)$. However, there was knockdown at concentrations $\geq 10 \%$ of field rate $(1 \mathrm{mg} /$ liter $)$. The $\mathrm{LC}_{50}(24 \mathrm{~h})$ for aphids was $10.57 \%$ of field rate $(1.057 \mathrm{mg} /$ liter) (Table 1), with total knockdown of aphids occurred at $3.2 \%$ of field rate (0.32 mg/liter) (Table 2).

The $\mathrm{LC}_{50}(24 \mathrm{~h})$ for lacewings exposed to dimethoate was $0.17 \%$ of field rate $(2.04 \mathrm{mg} /$ liter) (Table 1), with $100 \%$ knockdown at $0.18 \%$ of field rate $\left(2.16 \mathrm{mg}\right.$ /liter). The $\mathrm{LC}_{50}(24 \mathrm{~h})$ for aphids was $0.02 \%$ of field rate $(0.24 \mathrm{mg} /$ liter $)$, with $100 \%$ knockdown at $0.1 \%$ of field rate $(1.2 \mathrm{mg} /$ liter) (Table 1 and Table 3 ).

Enzyme Activity. Lambda-cyhalothrin had no effect on ChE activity in surviving lacewings, with no concentration response, and there was also no correlation between mortality and ChE activity $(r=0.013)$ (Table 2). Cholinesterase activity was significantly inhibited in aphids surviving exposure to lambda-cyhalothrin $(F=1.4 ; \mathrm{df}=4,18 ; P=0.006)$, and this inhibition followed a linear trend $(F=1.1 ; \mathrm{df}=1,18$; $P<0.001$ ). Aphid mortality was negatively correlated with ChE activity $(r=-0.93, P=0.023)$.

Cholinesterase activity was significantly inhibited in lacewings surviving exposure to dimethoate $(F=32.4$; $\mathrm{df}=6,36 ; P<0.001)$, and this followed a linear trend $(F=31.5 ; \mathrm{df}=1,36 ; P<0.001)$ (Table 3). Mortality was negatively correlated with enzyme activity $(r=$ $-0.84, P=0.038)$. Cholinesterase activity in aphids surviving exposure to dimethoate also was significantly inhibited $(F=4.7 ; \mathrm{df}=3,12 ; P<0.001)$, and this inhibition followed a linear trend $(F=4.6 ; \mathrm{df}=$

Table 2. Laboratory effects of lambda-cyhalothrin on mortality (mean \pm SE) of lacewings and aphids, and ChE activity (nanomoles of ATCh hydrolyzed/min/mg protein and GST activity (nanomoles of GSH conjugated $/ \mathrm{min} / \mathrm{mg}$ protein) in survivors

\begin{tabular}{|c|c|c|c|c|c|c|}
\hline $\begin{array}{c}\text { Concn } \\
\text { (\% of field rate) }\end{array}$ & $\begin{array}{l}\text { Lacewing } \\
\text { mortality }\end{array}$ & $\begin{array}{c}\text { Aphid } \\
\text { mortality }\end{array}$ & $\begin{array}{l}\text { Lacewing } \\
\text { ChE }\end{array}$ & $\begin{array}{l}\text { Lacewing } \\
\text { GST }\end{array}$ & Aphid ChE & Aphid GST \\
\hline 0 & $0 \pm 0$ & $20 \pm 0$ & $79.7 \pm 31.9$ & $99.4 \pm 21.0$ & $175.6 \pm 23.6$ & $2,532 \pm 577$ \\
\hline 1 (0.1 mg/liter $)$ & $5 \pm 3$ & $28 \pm 5$ & $51.0 \pm 8.5$ & $118.4 \pm 35.0$ & $188.3 \pm 42.3$ & $2,390 \pm 599$ \\
\hline $3.2(0.32 \mathrm{mg} /$ liter $)$ & $10 \pm 3$ & $55 \pm 13$ & $74.6 \pm 20.5$ & $103.8 \pm 21.4$ & $149.0 \pm 18.7$ & $2,588 \pm 1,003$ \\
\hline $10(1 \mathrm{mg} /$ liter $)$ & $10 \pm 3$ & $58 \pm 5$ & $61.2 \pm 15.0$ & $98.2 \pm 27.8$ & $110.7 \pm 7.1$ & $3,414 \pm 1,216$ \\
\hline $32(3.2 \mathrm{mg} /$ liter $)$ & $30 \pm 5$ & $88 \pm 5$ & $67.5 \pm 9.0$ & $170.2 \pm 48.4$ & $94.3 \pm 41.0$ & $2,831 \pm 816$ \\
\hline $100(10 \mathrm{mg} /$ liter $)$ & $15 \pm 5$ & $100 \pm 0$ & $83.8 \pm 7.8$ & $93.7 \pm 35.9$ & N.S. & N.S. \\
\hline
\end{tabular}

N.S., no survivor. 
Table 3. Laboratory effects of dimethoate on mortality (mean \pm SE) of lacewings and aphids, and ChE activity (nanomoles of ATCh hydrolysed/min/mg protein and GST activity (nanomoles of GSH conjugated/min/mg protein) in survivors

\begin{tabular}{|c|c|c|c|c|c|c|}
\hline $\begin{array}{c}\text { Concn } \\
\text { (\% of field rate) }\end{array}$ & $\begin{array}{l}\text { Lacewing } \\
\text { mortality }\end{array}$ & $\begin{array}{l}\text { Aphid } \\
\text { mortality }\end{array}$ & Lacewing ChE & Lacewing GST & Aphid ChE & Aphid GST \\
\hline 0 & $0 \pm 0$ & $38 \pm 10$ & $79.7 \pm 31.9$ & $64.2 \pm 20.2$ & $115.2 \pm 30.9$ & $2,188 \pm 323$ \\
\hline 0.01 (0.12 mg/liter $)$ & $5 \pm 3$ & $38 \pm 19$ & $94.7 \pm 11.0$ & $56.9 \pm 10.9$ & $109.3 \pm 27.0$ & $2,567 \pm 663$ \\
\hline $0.032(0.38 \mathrm{mg} /$ liter $)$ & $0 \pm 0$ & $58 \pm 15$ & $48.0 \pm 7.0$ & $63.1 \pm 19.5$ & $58.7 \pm 31.5$ & $2,617 \pm 793$ \\
\hline 0.10 (1.2 mg/liter $)$ & $23 \pm 6$ & $85 \pm 13$ & $20.6 \pm 9.6$ & $78.4 \pm 21.3$ & $20.1 \pm 4.9$ & $3,482 \pm 1,431$ \\
\hline 0.32 (3.8 mg/liter) & $88 \pm 6$ & $100 \pm 0$ & $3.9 \pm 0.8$ & $56.0 \pm 1.1$ & N.S. & N.S. \\
\hline 1.0 (12 mg/liter) & $95 \pm 4$ & $100 \pm 0$ & $0.2 \pm 0.0$ & $50.1 \pm 0$ & N.S. & N.S. \\
\hline
\end{tabular}

$3,12 ; P<0.001)$. Aphid mortality was negatively correlated with enzyme activity $(r=-0.99, P=0.013)$.

GST activity was not affected in surviving lacewings or aphids exposed to either lambda-cyhalothrin (Table 2) or dimethoate (Table 3). There were no significant correlations between mortality and GST activity for either species or insecticide.

Field Experiments. Mortality. The success rate in finding lacewings or aphids placed in the muslin bags was low, with only $35.7 \%$ of lacewings and $52.7 \%$ of aphids being recovered (Table 4 and 5). In the lambda-cyhalothrin plots, both species showed a lack of dose response; therefore, reliable $\mathrm{LC}_{50}$ values were not able to be determined for either species for this pesticide. This was also the case for lacewings exposed to dimethoate, but for aphids the $\mathrm{LC}_{50}$ value was $0.96 \%$ of field rate (11.5 mg/liter) (Table 1).

Enzyme Activity. Due to the low recapture rate, there were insufficient individuals for enzyme analyses of individual replicates for ChE activity (a minimum of three animals are required per sample). Therefore, animals for each treatment were pooled, giving only one value for enzyme activity for each concentration for each pesticide and species. Consequently, statistical analysis of data was not possible, and results are based on trends only.

Cholinesterase activity in lacewings did not follow a normal dose-response curve with increasing concentration of lambda-cyhalothrin or dimethoate. This was also the case for aphids exposed to lambda-cyhalothrin, but dimethoate seemed to have an inhibitory effect (activity at $3.2 \%$ of field rate was $<10 \%$ of that in the control) (Tables 4 and 5).

GST activity in lacewings exposed to lambda-cyhalothrin seemed to increase with increasing pesticide concentration. For example, activity in lacewings exposed to 10,32 , and $100 \%$ of field rate were $3.5,3.2$, and 4.1 times higher than in the controls respectively.
There was no dose response for lacewings exposed to dimethoate or in aphids exposed to either pesticide, but the aphids exposed to $10 \%$ of field rate of dimethoate showed a 3.4-fold increase in GST activity compared with the controls (Table 4 and 5). For a summary of enzyme responses in the laboratory and field, see Table 6 .

\section{Discussion}

The development of insecticide resistance in pest species is a major concern for growers, and is, or should be, a driver in the use of reduced application rates or other IPM strategies to control these pests (Dent 2000). There are two main mechanisms of insecticide resistance: increased detoxification of the insecticide and a decreased affinity with the target protein. For example, resistance in some pest species is associated with increased detoxification by GST or by decreased sensitivity of cholinesterase to organophosphates (Rufinger et al. 1999). Therefore, measurement of these two enzymes is not only useful as an indicator of the health of surviving natural enemies but also may be useful for measuring or monitoring possible insecticide resistance in the pest species. Furthermore, measurement of biomarker responses may be used to show that animals have been exposed to insecticides, e.g., via spray drift.

In the laboratory toxicity tests, lacewings were less sensitive than were aphids to both insecticides. Lacewings were not significantly affected by lambdacyhalothrin, and even when exposed to the recommended field application rate there was no significant mortality. Lacewing larvae are thought to have a high natural tolerance to pyrethroids (Hurej and Dutcher 1994), and these laboratory studies support this hypothesis. Bigler and Waldburger (1994) evaluated the effects of pesticides on C. carnea larval and pupal

Table 4. Field effects of lambda-cyhalothrin on mortality (mean \pm SE) in lacewings and aphids, and GST and ChE activities in survivors

\begin{tabular}{|c|c|c|c|c|c|c|c|c|}
\hline $\begin{array}{c}\text { Concn } \\
\text { (\% of field rate) }\end{array}$ & $\begin{array}{c}\text { Lacewing } \\
\text { recapture }(\%)\end{array}$ & $\begin{array}{c}\text { Aphid } \\
\text { recapture }(\%)\end{array}$ & $\begin{array}{c}\text { Lacewing } \\
\text { mortality }(\%)\end{array}$ & $\begin{array}{c}\text { Aphid } \\
\text { mortality (\%) }\end{array}$ & $\begin{array}{c}\text { Lacewing } \\
\text { ChE }\end{array}$ & $\begin{array}{l}\text { Aphid } \\
\text { ChE }\end{array}$ & $\begin{array}{l}\text { Lacewing } \\
\text { GST }\end{array}$ & $\begin{array}{c}\text { Aphid } \\
\text { GST }\end{array}$ \\
\hline 0 & $36 \pm 30$ & $52 \pm 36$ & $19 \pm 24$ & $23 \pm 26$ & 99.1 & 42.5 & 24.91 & 2,397 \\
\hline 1 (0.1 mg/liter $)$ & $16 \pm 26$ & $68 \pm 30$ & $0 \pm 0$ & $38 \pm 41$ & 179.0 & 30.0 & 38.61 & 2,023 \\
\hline $3.2(0.32 \mathrm{mg} /$ liter $)$ & $48 \pm 23$ & $44 \pm 38$ & $40 \pm 42$ & $13 \pm 16$ & 105.0 & 47.2 & 51.83 & 2,428 \\
\hline $10(1 \mathrm{mg} /$ liter $)$ & $28 \pm 23$ & $48 \pm 30$ & $13 \pm 25$ & $44 \pm 34$ & 77.4 & 38.2 & 88.0 & 3,746 \\
\hline 32 (3.2 mg/liter) & $44 \pm 36$ & $68 \pm 18$ & $50 \pm 41$ & $24 \pm 43$ & 108.7 & 57.3 & 79.37 & 2,947 \\
\hline 100 (10 mg/liter $)$ & $32 \pm 11$ & $52 \pm 41$ & $80 \pm 27$ & $28 \pm 38$ & N.T. & 54.8 & 101.27 & 2,561 \\
\hline
\end{tabular}

N.T., insufficient animals for analysis. 
Table 5. Field effects of dimethoate on mortality (mean \pm SE) in lacewings and aphids, and GST and ChE activities in survivors

\begin{tabular}{|c|c|c|c|c|c|c|c|c|}
\hline $\begin{array}{c}\text { Concn } \\
\text { (\% of field rate) }\end{array}$ & $\begin{array}{c}\text { Lacewing } \\
\text { recapture }(\%)\end{array}$ & $\begin{array}{c}\text { Aphid } \\
\text { recapture }(\%)\end{array}$ & $\begin{array}{c}\text { Lacewing } \\
\text { mortality }(\%)\end{array}$ & $\begin{array}{c}\text { Aphid } \\
\text { mortality (\%) }\end{array}$ & $\begin{array}{l}\text { Lacewing } \\
\text { ChE }\end{array}$ & $\begin{array}{l}\text { Aphid } \\
\text { ChE }\end{array}$ & $\begin{array}{l}\text { Lacewing } \\
\text { GST }\end{array}$ & $\begin{array}{c}\text { Aphid } \\
\text { GST }\end{array}$ \\
\hline 0 & $32 \pm 27$ & $52 \pm 48$ & $17 \pm 33$ & $25 \pm 43$ & 99.1 & 42.5 & 24.91 & 2,397 \\
\hline 1 (12 mg/liter) & $32 \pm 18$ & $44 \pm 36$ & $50 \pm 50$ & $18 \pm 24$ & NT & 23.3 & 56.19 & 4,162 \\
\hline 3.2 (38.4 mg/liter) & $32 \pm 22$ & $52 \pm 41$ & $25 \pm 50$ & $60 \pm 36$ & 78.6 & 4.1 & 56.56 & 2,276 \\
\hline 10 (120 mg/liter $)$ & $32 \pm 23$ & $44 \pm 43$ & $25 \pm 50$ & $88 \pm 25$ & 52.8 & N.T. & 34.74 & 8,226 \\
\hline 32 (384 mg/liter) & $48 \pm 33$ & $56 \pm 30$ & $41 \pm 38$ & $96 \pm 9$ & 130.5 & N.T. & 32.65 & N.T. \\
\hline 100 (1,200 mg/liter $)$ & $48 \pm 23$ & $52 \pm 43$ & $63 \pm 42$ & $100 \pm 0$ & 59.7 & N.S. & 66.26 & N.S. \\
\hline
\end{tabular}

N.S., no survivors; N.T., insufficient animals for analysis.

mortality in the laboratory, and exposure to $37.5 \mathrm{mg}$ / liter lambda-cyhalothrin (almost 4 times the field rate) caused only $24 \%$ mortality. In contrast to lacewing larvae, aphids were sensitive to lambda-cyhalothrin, with $88 \%$ mortality at $32 \%$ of the recommended field application rate.

Dimethoate caused high mortality to both lacewings and aphids at concentrations $<1 \%$ of the recommended application rate, i.e., $\mathrm{LC}_{50}$ values were 0.17 and $0.02 \%$ of the recommended field application rates for lacewings and aphids, respectively (2.04 and 0.24 $\mathrm{mg} /$ liter respectively). The toxicity of dimethoate to the brown lacewing is comparable with that for $C$. rufilabris Burmeister larvae, which had an $\mathrm{LC}_{50}$ of 5.4 $\mathrm{mg} /$ liter (95\% CI, 2.9-8.3) (Mizell and Schiffhauer 1990). Based on the current laboratory study, the extreme toxicity of dimethoate to both lacewings and aphids at the recommended field application rate in the laboratory suggests that the application rate of this pesticide could be reduced considerably and still remain effective against aphids. Furthermore, there seemed to be a difference in sensitivity between the two species. At $0.1 \%$ of the recommended field application rate, $85 \%$ of aphids were killed, whereas the mortality in lacewings was only $23 \%$. However at $0.32 \%$ of field rate, mortality in both species was close to

Table 6. Summary of organism enzyme responses

\begin{tabular}{|c|c|c|c|c|}
\hline \multirow{2}{*}{$\begin{array}{l}\text { Species and } \\
\text { enzyme }\end{array}$} & \multicolumn{2}{|c|}{ Dimethoate } & \multicolumn{2}{|c|}{ Lambda-cyhalothrin } \\
\hline & $\begin{array}{l}\text { Expected } \\
\text { response }\end{array}$ & $\begin{array}{c}\text { Actual } \\
\text { response }\end{array}$ & $\begin{array}{l}\text { Expected } \\
\text { response }\end{array}$ & $\begin{array}{c}\text { Actual } \\
\text { response }\end{array}$ \\
\hline \multicolumn{5}{|l|}{ Laboratory } \\
\hline \multicolumn{5}{|l|}{ Lacewing } \\
\hline ChE activity & $\downarrow$ & $\downarrow(P<0.001)$ & $\mathrm{N}$ & $\mathrm{N}$ \\
\hline \multirow{2}{*}{\multicolumn{5}{|c|}{ Aphid }} \\
\hline & & & & \\
\hline ChE activity & $\downarrow$ & $\downarrow \quad(P=0.001)$ & $\mathrm{N}$ & $\downarrow(P=0.006)$ \\
\hline GST activity & $\uparrow$ & $\mathrm{N}$ & $\uparrow$ & $\mathrm{N}$ \\
\hline \multicolumn{5}{|l|}{ Field $^{a}$} \\
\hline \multicolumn{5}{|l|}{ Lacewing } \\
\hline ChE activity & $\downarrow$ & $\mathrm{N}$ & $\mathrm{N}$ & $\mathrm{N}$ \\
\hline GST activity & $\uparrow$ & $\mathrm{N}$ & $\uparrow$ & $\uparrow$ \\
\hline \multicolumn{5}{|l|}{ Aphid } \\
\hline ChE activity & $\downarrow$ & $\downarrow$ & $\mathrm{N}$ & $\mathrm{N}$ \\
\hline GST activity & $\uparrow$ & $\uparrow$ & $\uparrow$ & $\mathrm{N}$ \\
\hline
\end{tabular}

$\downarrow$, enzyme activity inhibited; , enzyme activity increased; $\mathrm{N}$, enzyme activity did not respond in a dose-dependent manner.

${ }^{a}$ Field results are based on pooled samples, giving only one value for enzyme activity for each concentration for each pesticide and species. See text for details.
$100 \%$, indicating that dimethoate has a very steep concentration-response curve.

These laboratory results suggest that reducing application rates for these two insecticides could be important in selectively killing aphids, while enhancing survival of the beneficial lacewing. However, in the field the results were not as clear-cut. This was in part due to the low recapture rate, especially for the lacewings. Hodge et al. (2000) have previously successfully used drawstring bags with lacewings in the field, but this work was conducted using adults, rather than larvae. The bags provide a realistic method of exposure as the animals are free to move round the leaf, which simulates more closely the real situation. But it was difficult to secure the drawstring tightly enough round the leaf to prevent escape of the organisms without damaging the leaf. Therefore, in future, it would be advisable to use clip cages. The disadvantage of these, however, is that the organism is maintained on one side of the leaf only and the cages can damage the leaves.

The low recapture rate makes it difficult to draw any conclusions from the field trial and the data are also very variable. This is not unexpected, due to a range of factors, including pesticide application rates on individual leaves, differences in pesticide application on different parts of the leaf, weather, and other environmental factors. This does highlight the fact that field conditions are more complex and that it is difficult to repeat laboratory results under natural conditions. It indicates that more effort should be spent to test responses under field conditions. Lambda-cyhalothrin had no apparent effect on aphid mortality in the field, even at the recommended application rate, despite that in the laboratory, the $\mathrm{LC}_{50}$ for this species was $10.57 \%$ of field rate, and mortality was almost $100 \%$ at concentrations as low as $32 \%$ of field rate. Conversely, lacewings exhibited significant mortality in the field at the normal application rate, but no mortality in the laboratory at this rate.

Dimethoate, however, gave a clear concentration response in aphids. As expected from the laboratory trials, aphids were more sensitive to this insecticide than were the lacewings. However, dimethoate was far less toxic in the field than in the laboratory. This is probably because of the reasons given above. In addition, studies with fluorescent spray tracer showed that deposition levels decline down through the canopy, but this is affected by a number of factors, in- 
cluding crop density, growth stage, environmental conditions, and application rates and volumes (Cigli and Jepson 1992).

Despite lower mortality rates in the field, these results suggest that the application rate for dimethoate could be reduced significantly and that this should still be highly effective against aphids, while protecting the lacewings. These results are consistent with other studies where pesticide application rates have been reduced considerably but still maintained efficacy against the target species (Wiles and Jepson 1995). Such an understanding of tritrophic interactions in crops can contribute to improvements in the longterm control of insect pests (Verkerk et al. 1998). Pest suppression by natural enemies such as lacewing may ultimately reduce the number of insecticide applications and may therefore help decrease the likelihood of the development of resistance in pest species (Dent 1991). Moreover, decreasing the dose of insecticide application has been identified as one of 10 tactics to manage pesticide resistance (Roush and Daly 1990). However, there is still doubt in the community about the effect of applying sublethal dose rates on the development of resistance (McKenzie 1996), and Roush (1989) referred the manipulation of dose rates to delay resistance as a "dead end trail" (for review, see Denholm and Rowland (1992)). Nevertheless, the financial savings from using reduced application rates can be significant. For example, Mann et al. (1991) found better economic returns when reduced rates were applied.

Dimethoate exposure in the laboratory caused a significant inhibition of ChE activity in both lacewings and aphids, and this inhibition occurred in a concentration-dependent manner. For lacewings, ChE activity was significantly inhibited below concentrations that produced a noticeable effect on mortality or knockdown, i.e., the lowest effect level (LEL) was $0.1 \%$ of field rate $(1.2 \mathrm{mg} /$ liter $)$, and this LEL corresponded with only $23 \%$ mortality ( $23 \%$ knockdown). This finding is consistent with previous experiments where lacewings were exposed to two other organophosphates, diazinon and chlorpyrifos, and ChE activity was significantly inhibited in the absence of any effect on mortality (Hodge et al. 2000). Conversely, for aphids, significant inhibition of ChE activity was observed only at a concentration that resulted in very high mortality, i.e., the LEL for aphids, as for lacewings, was $0.1 \%$ of field rate and this corresponded with $85 \%$ mortality and $100 \%$ knockdown. This finding indicates that the threshold for lethal effects in the aphid is very close to that for effects on ChE activity, but not in the lacewing.

There are no previous reports of inhibition of ChE activity by lambda-cyhalothrin; and indeed, some authors have reported an increase, e.g., the red flour beetle, Tribolium castaneum (Herbst), showed enhanced activity after exposure to lambda-cyhalothrin (Shakoori et al. 1994, Ahmad et al. 2003). In the current research, this insecticide had no effect on $\mathrm{ChE}$ activity in lacewings, but activity in the aphid was significantly reduced at $3.2 \mathrm{mg} /$ liter $(32 \%$ of field rate). At this concentration, $88 \%$ of aphids were killed and the survivors suffered from total knockdown, i.e., the response was very similar to that observed for dimethoate. However, $\mathrm{ChE}$ activity was reduced by only $46 \%$ compared with controls, whereas dimethoate reduced $\mathrm{ChE}$ activity by almost $83 \%$ compared with controls at a concentration that caused a similar mortality. Therefore, this result may be because the aphids were already very close to death. However, this hypothesis should be investigated further.

The absence of an effect of dimethoate on GST activity in either species was consistent with previous research examining the effects of organophosphates on GST activity in lacewings. There were no changes in GST activity in lacewing L3 larvae exposed to two organophosphates, methyl-parathion and azinphosmethyl, although exposure to the pyrethroid cypermethrin did induce GST activity (Rumpf et al. 1997). Hodge et al. (2000) found no induction of GST activity in adult lacewings exposed to two other organophosphates, diazinon or chlorpyrifos. There is one report of induction of GST activity in response to dimethoate, but this induction was in rats and occurred only after repeated oral dosing with dimethoate (El-Sharkawy et al. 1994)

In conclusion, the high mortality rate observed for lacewings and aphids exposed to dimethoate in the field suggests that the application rate could be reduced significantly and still remain efficacious against aphids, while protecting the beneficial lacewing. Measurement of ChE activity could provide a useful indicator of the ecological fitness of survivors to give a more complete assessment of the value of reduced rate insecticide use.

\section{Acknowledgments}

We thank Bruce Snowdon for assistance and Alison Lister for statistical analysis. This project was funded by the Foundation for Research, Science and Technology, New Zealand.

\section{References Cited}

Ahmad, I., R. R. Ali, R. Tabassum, and M. A. Azmi. 2003. Cholinesterase activity and protein contents after treatment with some insecticides in red flour beetle, Tribolium castaneum PARC strain. J. Exp. Zool. India 6: 307-312.

Bigler, F., and M. Waldburger. 1994. Effects of pesticides on. Chrysoperla carnea Steph. (Neuroptera, Chrysopidae) in the laboratory and semi-field. Bull. OILB SROP 17: 55-69.

Booth, L. H., and K. O'Halloran. 2001. A comparison of biomarker responses in the earthworm Aporrectodea caliginosa to the organophosphorus insecticides diazinon and chlorpyrifos. Environ. Toxicol. Chem. 20: 2494-2502.

Bradford, M. M. 1976. A rapid and sensitive method for the quantitation of microgram quantities of protein utilizing the principle of protein-dye binding. Anal. Biochem. 72: $248-254$.

Burn, A. J., T. H. Coaker, and P. C. Jepson. 1987. Integrated pest management. Academic, London, United Kingdom. 
Cigli, T., and P. C. Jepson. 1992. The use of tracers to estimate the exposure of insects to direct pesticide spraying in cereals. Ann. Appl. Biol. 121: 239-247.

Day, K. E., and I. M. Scott. 1990. Use of acetylcholinesterase activity to detect sublethal toxicity in stream invertebrates exposed to low concentrations of organophosphate insecticides. Aquat. Toxicol. 18: 101-114.

Denholm, I., and M. W. Rowland. 1992. Tactics for managing pesticide resistance in arthropods: theory and practice. Annu. Rev. Entomol. 37: 91-112.

Dent, D. 1991. Insect pest management, CABI Publishing, Wallingford, United Kingdom.

Dent, D. 2000. Insect pest management, 2nd ed. CABI Publishing, Wallingford, United Kingdom.

Edwards, C. A., and S. W. Fisher. 1991. The use of cholinesterase measurements in assessing the impacts of pesticides on terrestrial and aquatic invertebrates, pp. $256-$ 275. In P. Mineau [ed.], Cholinesterase-inhibiting insecticides: their impact on wildlife and the environment. Elsevier, Amsterdam, The Netherlands.

Ellman, G. L., K. D. Courtenay, A. J. Valentino, and E. M. Featherstone. 1961. A new rapid colorimetric determination of acetylcholinesterase activity. Biochem. Pharmacol. 7: 88-95.

El-Sharkawy, A. M., S. Z. Abdel-Rahman, A. A. Hassan, M. H. Gabr, S. M. El-Zoghby, and S. M. El-Sewedy. 1994. Biochemical effects of some insecticides on the metabolic enzymes regulating glutathione metabolism. Bull. Environ. Contam. Toxicol. 52: 505-510.

Engenheiro, E. L., P. K. Hankard, J. P. Sousa, M. F. Lemos, and J. M. Weeks. 2005. Influence of dimethoate on acetylcholinesterase activity and locomotor function in terrestrial isopods. Environ. Toxicol. Chem. 24: 603-609.

Gautam, R. D., and A. Tesfaye. 2000. Potential of green lacewing Chrysoperla carnea (Stephens) in crop pest management. N. Agric. 13: 147-158.

Habig, W. H., M. J. Pabst, and W. B. Jacoby. 1974. Glutathione $\mathrm{S}$-transferases, the first enzymatic step in mercapturic acid formation. J. Biol. Chem. 249: 321-336.

Hodge, S., M. Longley, L. Booth, V. Heppelthwaite, and K. O'Halloran. 2000. Cholinesterase activity in the Tasmanian lacewing as a biomarker for organophosphorus pesticides. Aust. J. Ecotoxicol. 6: 109-116.

Hurej, M., and J. D. Dutcher. 1994. Indirect effect of insecticides used in pecan orchards to larvae of Chrysoperla rufilabris (Neuroptera: Chrysopidae). J. Econ. Entomol. 29: $450-456$.

Hyne, R. V., and W. A. Maher. 2003. Invertebrate biomarkers: links to toxicosis that predict population decline. Ecotoxicol. Environ. Saf. 54: 366-374.

Jensen, C. S., L. Garsdal, and E. Baatrup. 1997. Acetylcholinesterase inhibition and altered locomotor behaviour in the carabid beetle Pterostichus cupreus. A linkage between biomarkers at two levels of biological complexity. Environ. Toxicol. Chem. 16: 1727-1732.

Krishnamoorthy, A. 1985. Effect of several pesticides on eggs, larvae and adults of the green lacewing Chrysopa scelestes Banks. Entomol. 10: 21-28.

Lagadic, L., A. Cuvany, J. Berge, and M. Echaubard. 1993. Purification and partial characterisation of glutathioneS-transferases from insecticide-resistant and Lindane-induced susceptible. Spodoptera littoralis (Boisd) larvae. Insect Biochem. Mol. Biol. 23: 467-474.

Lamoureux, G. L., and D. G. Rusness. 1987. Synergism of diazinon toxicity and inhibition of diazinon metabolism in the house fly by Tridiphane: inhibition of glutathione-Stransferase activity. Pestic. Biochem. Physiol. 27: 318-329.
Madsen, H. F., and K. Williams. 1968. Effectiveness and persistence of low dosages of azinphos methyl control of the codling moth. J. Econ. Entomol. 64: 693-697.

Mann, B. P., S. D. Wratten, M. Poehling, and C. Borgemeister. 1991. The economics of reduced-rate insecticide applications to control aphids in winter wheat. Ann. Appl. Biol. 119: 451-464.

McCarthy, J. F., and L. R. Shugart. 1990. Biomarkers of environmental contamination. Lewis Publishers, Boca Raton, FL.

McKenzie,J.A. 1996. Ecological and evolutionary aspects of insecticide resistance. Academic, Austin, TX.

Metcalf, R. L. 1980. Changing role of insecticides in crop protection. Annu. Rev. Entomol. 25: 219-256.

Mizell, R. F., and D. E. Schiffhauer. 1990. Effects of pesticides on pecan aphid predators Chrysoperla rufilabris (Neuroptera: Chrysopidae), Hippodamia convergens, Cycloneda sanguinea (L.), Olla v-nigram (Coleoptera: Coccinellidae), and Aphelinus perpallidus (Hymenoptera: Encyrtidae). J. Econ. Entomol. 83: 1806-1812.

Motoyama, N. 1980. Glutathione-S-transferases: their role in the metabolism of organophosphorus insecticides. Rev. Biochem. Toxicol. 2: 49-69.

Oppenoorth, F. J., H. R. Smissaret, W. Welling, L.J.T. Van der Pas, and K. T. Hitman. 1977. Insensitive acetylcholinesterase, high glutathione-S-transferase and hydrolytic activity as resistance factors in a tetrachlorofervinphosresistant strain of houseflies. Pestic. Biochem. Physiol. 7: $34-47$.

Parkes, T. L., A. J. Hilliker, and J. P. Phillips. 1993. Genetic and biochemical analysis of glutathione-S-transferase in the oxygen defence system of. Drosophila melanogaster. Genome 36: 1007-1014.

Pimentel, D., C. Wilson, C. McCullum, R. Huang, P. Dwen, J. Flack, Q. Tran, T. Saltman, and B. Cliff. 1997. Economic and environmental benefits of biodiversity. Bioscience 47: 747-757.

Poehling, H. M. 1988a. Control of cereal aphids in winter wheat with reduced dose rates of different insecticides with special respect to side effects to beneficial arthropods, pp. 135-146. In R. Cavalloro and K. D. Sunderland [eds. ], Proceedings of the Meeting of EC Experts' Group "Integrated Crop Protection in Cereals," 25-27 November 1986, Littlehampton, A. A. Balkema, Rotterdam, The Netherlands.

Poehling, H. M. 1988b. Influence of cereal aphid control on aphid-specific predators in winter wheat (Homoptera: Aphididae). Entomol. Gen. 13: 163-174.

Poehling, H. M. 1989. Selective application strategies for insecticides in agricultural crops, pp. 151-175. In P. C. Jepson [ed.], Pesticides and non-target invertebrates. Intercept Ltd., Andover, United Kingdom.

Roush, R. T. 1989. Designing resistance management programs: how can you choose? Pestic. Sci. 26: 423-41.

Roush, R. T., and J. C. Daly. 1990. The role of population genetics in resistance research and management, pp. 97152. In R. T. Roush and B. E. Tabashnik [ed.], Pesticide resistance in arthropods. Chapman \& Hall, New York.

Rufinger, C., N. Pasteur, J. Lagnel, C. Martin, and M. Navajas. 1999. Mechanisms of insecticide resistance in the aphid Nasonovia ribisnigri (Mosley) (Homoptera: Aphididae) from France. Insect Biochem. Mol. Biol. 29: 385-391.

Rumpf, S. 1994. Effect of plant protection agents/chemicals on the metabolic organ, the fat body, in lacewings and the effects on reproduction and morphogenesis. Environmental Research Plan of the Federal Minister for the Environment, Conservation, and Reactor Safety, Berlin, 
Germany, Environmental Chemicals/Effects of Harmful Substances, Research Report 10603115.

Rumpf, S., F. Hetzel, and C. Frampton. 1997. Lacewings (Neuroptera: Hemerobiidae and Chrysopidae) and integrated pest management: enzyme activity as biomarker of sublethal insecticide exposure. J. Econ. Entomol. 90: 102108.

Shakoori, A. R., M. Z. Malik, and M. A. Saleem. 1994. Toxicity of cyhalothrin (Karate) to sixth instar larvae of Pakistani strain of Tribolium castaneum (Herbst) (Coleoptera: Tenebrionidae). Pak. J. Zool. 26: 57-64.

Smith, R. F., and R. van den Bosch. 1967. Integrated control, pp. 295-340. In W. W. Kilglore and R. L. Doutt [eds. ], Pest control: biological, physical and selected chemical methods. Academic, New York.

Solomon, M. G., J. V. Cross, J. D. Fitzgerald, C.A.M. Campbell, R. L. Jolly, R. W. Olszak, E. Niemczyk, and H. Vogt. 2002. Biocontrol of pests of apples and ears in northern and central Europe - 3. Predators. Biocontrol Sci. Technol. 10: 91-128.

Stern, V. M., R. F. Smith, R. van den Bosch, and K. S. Hagen. 1959. The integrated control concept. Hilgardia 29: 81101.
Syrett, P., and D. R. Penman. 1980. Studies of insecticide toxicity to Lucerne aphids and their predators. N.Z. J. Agric. Res. 23: 575-580.

van den Bosch, R., and V. M. Stern. 1962. The integration of chemical and biological control of arthropod pests. Annu. Rev. Entomol. 7: 367-386.

Verkerk, R.H.J., S. R. Leather, and D. J. Wright. 1998. The potential for manipulating crop-pest-natural enemy interactions for improved insect pest. B. Enotomol. Res. 88: 493-501.

Wiles, J. A., and P. C. Jepson. 1995. Dosage reduction to improve the selectivity of deltamethrin between aphids and coccinellids in cereals. Entomol. Exp. Appl. 76: 83-96.

Yang, R.S.H. 1976. Enzyme conjugation and insecticide metabolism, pp. 177-181. In C. F. Wilkinson [ed.], Biochemistry and physiology of insecticides. Plenum, New York.

Zuazua, F., J. E. Araya, and M. A. Guerrero. 2003. Lethal effects of insecticides on Aphidus ervi Haliday (Hymenoptera: Aphidiidae), parasitoid of Acyrthosiphon pisum (Harris) (Homoptera: Aphidiidae). Bol Sanidad Vegetal, Plagas. 29: 299-307. 